Рад примљен: 1. 9. 2021.

Рад прихваћен: 16. 11. 2021.

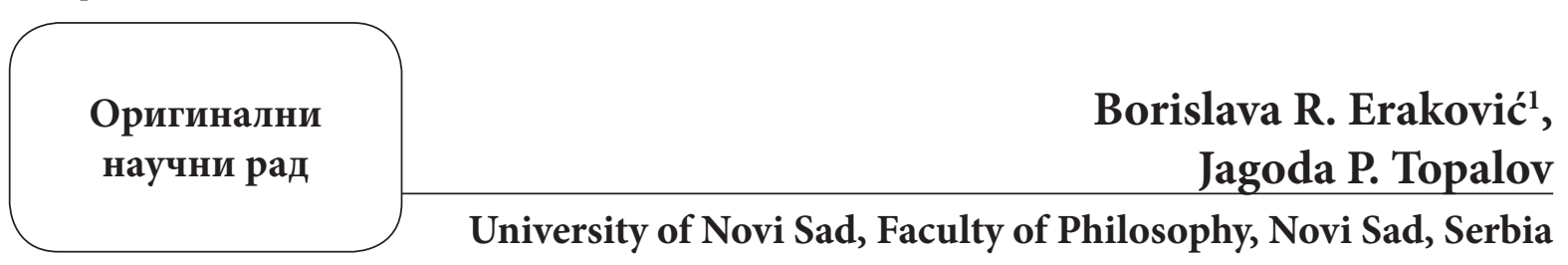

\title{
Teaching and Learning Through Moodle, Google Doc and Zoom: Fostering Student Engagement in (A)Synchronous Learning Environments ${ }^{2}$
}

\begin{abstract}
Summary: Collaborative online learning depends on the teacher's ability to create conditions for student interaction and engagement. The paper presents the type of activities that can foster them, as well as the results of the investigation into the levels of student engagement in online learning environment which was created by a combination of Moodle, Zoom and Google Documents. The focus is on the level of student engagement in relation to the type of interaction in the online learning environment, their previous experience with blended learning and their overall attitudes toward online classes. Toward this end, a convergent parallel mixed methods study was conducted by means of a 30-item questionnaire constructed for the purpose of this study. The questionnaire included both Likert-scale questions, aimed at collecting quantitative data, and open-ended questions, aimed at collecting qualitative data. Qualitative analysis of the respondents' comments reveals that online tools are most valued for their interactive and collaborative potential (the availability of emoticons, chatting and screen sharing in Zoom, the possibility of small group collaboration in Zoom Rooms and whole class collaboration in Google Docs). The most important quantitative results reveal that all students report medium to high levels of online classroom engagement in the presented scenarios. However, while the students who had previous experience with blended learning constructed their engagement on the basis of both online peer collaboration (in Zoom Rooms) and teacher-fronted instruction (Zoom), those with no previous experience with blended learning formed their engagement only on the basis of small group work (Zoom Rooms).
\end{abstract}

Keywords: socio-constructivist epistemology, distance learning, student collaboration, engagement.

\footnotetext{
1 E-mail: borislava.erakovic@ff.uns.ac.rs

2 The paper is based on research conducted as part of the project “Дигитализација универзитетске наставе језика, књижевности и културе: изазови, решења и перспективе у склопу одрживог развоја АП Војводине” (Digitalization of university teaching of language, literature and culture: challenges, solutions and perspectives within the sustainable development of Autonomous Province of Vojvodina; No.142-451-2260/2021-01/01). The project is financed by The Secretariat for Higher Education and Research of the Autonomous Province of Vojvodina.

Copyright (c) 2021 by the authors, licensee Teacher Education Faculty University of Belgrade, SERBIA.

This is an open access article distributed under the terms of the Creative Commons Attribution License (CC BY 4.0) (https://creativecommons.org/licenses/by/4.0/), which permits unrestricted use, distribution, and reproduction in any medium, provided the original paper is accurately cited.
} 


\section{Introduction}

Collaborative, project-based learning is an important segment in the teaching and learning scenarios based on social-constructivist epistemology (Vygotsky, 1978; Kiraly, 2000; Pešikan, 2010), according to which learners construct new knowledge through negotiation of meaning with more knowledgeable others (be they peers or teachers). This negotiation of meaning needs to take place within the zone of proximal development (ZPD), i.e. the area that is slightly above one's current skills and knowledge. In learner- and learning-centred approaches the teacher's role is to respond to learners' needs (stated explicitly by them or deduced by the teacher from the completed assignments), by guiding, facilitating and scaffolding. Studies have shown (cf. Kiraly, 2006:81; Kiraly et al., 2019:127-128) that guidance can take many forms (Herman \& Gomez, 2009), including frontal instruction, provided that it is introductory (about basic theoretical concepts), context-building, short, relevant for the identified problematic issues. In addition to developing student autonomy and self-reliance in learning, Kiraly (2015:18) believes that teachers also need to create conditions for students to work on translations on their own, so that their intuition in problem-solving activities can develop.

In a flipped-classroom instructional scenario (cf. Wanner \& Palmer, 2015:2; Eraković \& Lazović, 2017:262; Eraković, 2017), where students read on the subject and do assignments individually or in small groups previous to the class, most of these requirements can be fulfilled: the teacher can become aware of the students' ZPD by analysing the work they did in preparation for the class. In the class, the teacher can indicate problematic areas, propose questions for discussion, assign new reading materials and design new assignments and activities (cf. Kim et al., 2014:46; Kirschner et al., 2018:15; Boelens et al., 2018:4-5). Facilitating student collaboration and continuous engagement in a remote teaching and learning environment, however, is not a straightforward task, mostly because of the nature of online communication. In synchronous video conferencing, silences cannot last for too long (cf. Johnson, 2020:94), so if the students are reluctant to talk, the teacher risks turning back to the traditional, transmissionist mode of instruction. The asynchronous nature of some segments of remote teaching can, however, help in empowering students to be more autonomous and independent learners than they could be even in a face-to-face educational context (Wu \& Wei, 2021:303).

Having to turn to purely online mode of instruction due to the Covid-19 pandemic, teachers needed to devise new ways of keeping students involved and motivated in an online environment, and decide how much of the face-to-face materials, instructional methods and learning objectives can be transferred into remote teaching. Such a situation gave rise to a number of recent studies in 2020 and 2021, which focus on various issues in remote teaching in higher education: student-student and student-teacher interaction (Ahrens et al., 2021; Valentine \& Wong, 2021; Wang \& Wang, 2021), types of feedback and tools (Ahrens et al., 2021; Nordmann et al., 2020). While these studies shed light on a number of contextual factors influencing student involvement in online classes at university level, there is still much to be learned about the students' level of online engagement, understood as their invested behavioural, cognitive and affective effort in online academic work aimed at promoting knowledge, skills or crafts (Dörnyei, 2019:24; Fredricks et al., 2004:61). The goal of this paper is to investigate the level of student engagement in an online learning environment, with a particular focus on comparing the students who had past learning experiences with blended learning, in which the online environment was combined with in situ classes, and the students whose first encounter with the teacher and the course was in a purely online environment. 


\section{The concept of engagement}

Psychologists (Dörnyei, 2019:24; Fredricks et al., 2004:61) define engagement as active participation and involvement in certain behaviours. Although, in educational settings, this refers to students' participation and involvement in school activities and tasks and, as such, is manifested as observable behaviour (Kahu, 2013:759), engagement stems from internal psychological and social processes that develop over time, varying in intensity (Kahu, 2013:763). An increased level of internalization of this affective dimension among students influences behaviour in such a way that students display positive conduct and rule following, more involvement in learning, including time on task and asking questions, and decreased truancy (Fredricks et al., 2004:62). As a multifaceted and complex construct, engagement is also theorized to include the cognitive dimension, defined as the "investment in and effort directed toward learning, understanding, mastering the knowledge, skills or crafts that the academic work is intended to promote" (Newmann et al., 1992:12). At its core, the prototypical realization of engagement in the classroom is behavioural participation and, as such, it is connected with higher achievement (e.g. Finn \& Zimmer, 2012; Fredricks et al., 2004), self-efficacy and the pursuit of mastery goals (Christensen et al., 2012: v). Recent work has established that higher engagement is also connected with desired social and emotional academic outcomes (e.g. Klem \& Connell, 2004). Finally, as Reschly and Christenson (2006a, 2006b) point out, engagement is not solely an attribute of the student rather, it is an alterable concept that relies heavily on the interplay of a number of environmental factors, of which the most important are the capacity of school, family, and peers in providing steady expectations and support for learning.

\section{Research questions and educational context}

In order to investigate the level of student (dis)engagement in relation to the type of interaction in the online learning environment, their previous experience in blended learning and their overall attitudes toward online classes, we conducted a small-scale mixed methods study. To this end, a convergent parallel mixed methods design was implemented in order to answer the following research questions:

1) Do students differ in their level of (dis)engagement during synchronous online classes with respect to the mode of instruction (online vs. online/blended learning) they have been engaged in thus far?

2) Are there differences between students in their level of (dis)engagement with respect to their overall attitudes towards online classes?

3) What is the relative contribution of the type of interaction present in the students' online learning environment and its explanatory power in the students' level of (dis)engagement?

The participants of this study are 75 secondand third-year students at the Faculty of Philosophy, University of Novi Sad who attended three online courses: Translation of fiction (T1), Translation of scientific texts (T2) and Translation of legal texts (T3) from English into Serbian during the autumn semester in 2020. The courses were delivered through a combined use of Moodle, Google Docs and Zoom. While Moodle was used to store all the materials, assignments and links, Google Docs and Zoom (especially Zoom Rooms) were utilised to foster collaboration and discussions within small groups (up to three members) and the whole class.

In the investigation of student engagement in online courses, two subgroups can be identified. Group $1(\mathrm{G} 1, \mathrm{~N}=28)$ are third year students who had been exposed to blended learning environment in previous translation courses during the academic 2019/2020, while the other (G2, N=48) are second 
year students and they had not. All courses were taught by the same teacher.

Online lessons scenario. The general scenario in three online courses on translation was based on a few instructional routines, which Herman and
Gomez (2009: 64) define as 'a set of actions that are carried out by teachers and students within learning contexts' which 'rely broadly on tools'. Typical routines for the translation of a new text are presented in Table 1.

Table 1: Typical instructional routine for a translation assignment

\begin{tabular}{|c|c|c|}
\hline $\begin{array}{l}\text { Mode and type } \\
\text { of interaction }\end{array}$ & Online tools & Teacher $(\mathrm{T})$ and students' $(\mathrm{S})$ roles and activities \\
\hline entry into online session & $\begin{array}{l}\text { Moodle } \\
\text { Google Docs } \\
\text { Zoom }\end{array}$ & $\begin{array}{l}\text { S: entered the current week on Moodle, which contained a link to the } \\
\text { Google Docs (a working document for the day), where they wrote their } \\
\text { names and clicked on the link to enter the online session on Zoom. }\end{array}$ \\
\hline $\begin{array}{l}\text { synchronous } \\
\text { introductory session, } \\
\text { questions and answers } \\
\text { (Q\&A) }\end{array}$ & Zoom, video & $\begin{array}{l}\text { T: announced the topics, assignments and main parts for the day's ses- } \\
\text { sion, invited further suggestions, comments and questions from students. } \\
\text { S: responded verbally, through emoticons (Reactions on Zoom) or by } \\
\text { writing in chat. } \\
\text { While T. always had her camera on, S. could decide for themselves if they } \\
\text { wanted their cameras on or off. }\end{array}$ \\
\hline synchronous & $\begin{array}{l}\text { Zoom, } \\
\text { ppt on shared } \\
\text { screen }\end{array}$ & $\begin{array}{l}\text { T: introduced key concepts and terminology for the analysis of a particu- } \\
\text { lar type of translation, supported by a ppt presentation on shared screen } \\
\text { (5-10 minutes); opened breakout rooms on Zoom. } \\
\text { S: chose their collaborators in small groups by opting for a particular } \\
\text { Zoom room. }\end{array}$ \\
\hline $\begin{array}{l}\text { small group collabora- } \\
\text { tion }\end{array}$ & $\begin{array}{l}\text { Zoom rooms, } \\
\text { shared screens, } \\
\text { video conferencing } \\
\text { Google Docs }\end{array}$ & $\begin{array}{l}\text { S: worked on the assignment in small groups, discussed and analysed } \\
\text { extra-textual information relevant for the macro- and micro-textual fea- } \\
\text { tures of the excerpt. The excerpt was available in Google Docs to which } \\
\text { all S had access and could introduce comments and questions. } \\
\text { T: entered rooms upon an invitation from individual groups, followed } \\
\text { what the students were writing in Google Docs. If some questions S asked } \\
\text { were relevant for the whole class, T wrote it (colour coded red) in Google } \\
\text { Docs for everybody to see. }\end{array}$ \\
\hline $\begin{array}{l}\text { synchronous, } \\
\text { small group discussion } \\
\text { whole class writing }\end{array}$ & $\begin{array}{l}\text { Zoom rooms } \\
\text { Google Docs }\end{array}$ & $\begin{array}{l}\text { S: wrote the comments, insights and conclusions on which they agreed } \\
\text { in the Google Docs. }\end{array}$ \\
\hline $\begin{array}{l}\text { synchronous, } \\
\text { individual reading }\end{array}$ & Google Docs & $\begin{array}{l}\text { S, T: read the contributions of each group, highlighted the issues for } \\
\text { discussion, wrote short questions for further consideration in the com- } \\
\text { ments. }\end{array}$ \\
\hline $\begin{array}{c}\text { synchronous, } \\
\text { Q\&A, whole class dis- } \\
\text { cussion }\end{array}$ & $\begin{array}{l}\text { Zoom, Google } \\
\text { Docs on shared } \\
\text { screen }\end{array}$ & $\begin{array}{l}\text { S, T, discussed the highlighted issues, } \\
\text { exchanged arguments, until an agreement was reached. }\end{array}$ \\
\hline $\begin{array}{l}\text { asynchronous } \\
\text { individual translation }\end{array}$ & $\begin{array}{c}\text { Moodle } \\
\text { Google Docs }\end{array}$ & $\begin{array}{l}\text { S: individually translated the excerpt, taking into account the general } \\
\text { conclusions of the discussion (written in Google Docs) and posted them } \\
\text { as a response to the assignment on Moodle. }\end{array}$ \\
\hline
\end{tabular}




\begin{tabular}{cll}
\hline $\begin{array}{c}\text { synchronous } \\
\text { small group collabora- } \\
\text { tion }\end{array}$ & $\begin{array}{c}\text { Zoom rooms } \\
\text { Google Docs }\end{array}$ & $\begin{array}{l}\text { S: In small groups, negotiated the wording of the final version which is } \\
\text { based on their individual translations, posted it in Google Docs alongside } \\
\text { other groups' translations. }\end{array}$ \\
\hline $\begin{array}{c}\text { synchronous } \\
\text { whole class discussion }\end{array}$ & Google Docs & $\begin{array}{l}\text { S: highlighted the solutions they liked best in other groups translations. } \\
\text { T: highlighted segments in student translations which needed to be dis- } \\
\text { cussed further, and invited all students to offer arguments for or against } \\
\text { a particular solution. }\end{array}$ \\
\hline $\begin{array}{c}\text { asynchronous } \\
\text { individual feedback }\end{array}$ & Moodle & $\begin{array}{l}\text { For all collaborative translations that could not be discussed in class due } \\
\text { to time restrictions, the teacher sent individual feedback for each group's } \\
\text { translation to all members of the group and posted the best versions of } \\
\text { the translation on Moodle. }\end{array}$ \\
\hline
\end{tabular}

While students were collaborating in Zoom Rooms, the teacher was always aware of what they were doing through Google Docs, which was a proxy of a blackboard in a face-to-face classroom. If some groups did not leave comments, conclusions or questions in Google Docs, the teacher entered their breakout room to offer guidance. When all groups posted their translations (which were anonymous, marked only by the group number), students commented on them by highlighting what they believed were the best solutions in the posted versions. Since only the teacher knew which number stood for which group, this was a more objective peer assessment than it could have been in the classroom and was therefore more motivational (cf. Christensen et al., 2012:814). The teacher used a different colour to highlight the issues worthy of more consideration. This was a strong incentive for a whole class discussion in the main room in Zoom. The highlighted sections inspired students to comment and focus on details which would otherwise be overlooked. The teacher's choice to highlight instead of comment gave the students opportunity to come to a more considered solution within their small groups, which they often did.

Carless (2014:974), Nordmann et al. (2020) and Valentine and Wong (2021:221) report that the timing of the teacher's feedback can positively influence student engagement if it is as immediate as possible ('the same day feedback') and if it engages students in reflective discussions. In our context, students had regular practice in the assessment of translations through collaborative small-group work that required them to produce one final version of their group's translation on the basis of their three individual previously completed translations. Since all their group translations were followed by the teacher's feedback, they could also compare their arguments with the teacher's and this comparison was also an incentive for in-class discussions.

\section{Method}

Instrument. Upon completion of the online course, students were asked to anonymously answer a questionnaire in a Google form. It was made available through a link on Moodle. Their only identification was the name of the course attended. Overall, the questionnaire invited students' reflections regarding the tools used for collaborative assignments, presentation of learning materials and the type of instruction. It included both Likert-scale questions, aimed at collecting quantitative data and open-ended questions aimed at collecting qualitative data.

The quantitative segment of the survey included a four-factor solution, validated by means of a Principal Component Analysis, comprising the behavioural factor of Engagement and attitudinal factors of Perceived difficulty of online mode of instruction, Zoom Rooms, Zoom and Google Docs. Here we differentiate between the teacher's use of the Zoom in the introductory session and for feedback and we label it Zoom. Zoom Rooms refer to the 
online environment that allows the students to be divided into small (typically 3-member) groups that work on the assignment in their own space, are able to see each other, communicate and share screens. Google Docs are working documents to which all students in the class have simultaneous access. Items in the scale testing Engagement were formulated based on Aubrey et al. (2020), Dörnyei (2019) and Lopez (2011). The scale included statements such as: "The online learning environment provided me with opportunity to engage with my peers", or "[...] to engage with my teacher", which the respondents rated on a 5-point Likert scale ranging from 1 - I completely disagree, to 5 - I completely agree.

The initial version of the scale was tested for validity and reliability. The results of the analysis indicate that with respect to multicollinearity none of the values in the correlation matrix exceeded $r=$ .539. Kaiser-Meyer-Olkin measure confirmed the sampling adequacy for the analysis with a satisfactory $\mathrm{KMO}=.825$, whereas Bartlett's test of sphericity was statistically significant $(p<.000)$, indicating that correlation structure is adequate for factor analysis. The four-factor solution which resulted from the Kaiser's criterion of eigenvalues greater than 1 accounted for $70.05 \%$ of the variance. This was further checked for reliability of each factor, yielding the following satisfactory Kronbach's alphas: Engagement $-\alpha=.731$, Zoom $-\alpha=.742$, Zoom Rooms $-\alpha=.840$ and Google Docs $-\alpha=.812$.

Qualitative analysis was performed on the basis of questions which required from the respondents to state whether they attended sessions on Zoom, describe technical and other issues that prevented them from using Zoom, name the most effective tools that were used in online courses at the Faculty of Philosophy and explain what they (dis) liked about them.

Procedure. The qualitative data were first coded, after which, by means of an inductive approach, recurring patterns and categories were identified and a set of themes was organized. The quan- titative data were contrasted by means of a GLM ANOVA, following which a series of step-wise regressions were conducted in SPSS 25 statistical software.

\section{Results and Discussion}

Out of 170 students who were enrolled in the three translation courses, $87 \%$ regularly followed online courses through Zoom or Moodle or both. Less than half of them ( $44 \%$ or 75 ) responded to the combined questionnaire.

Qualitative analysis of the answers to open questions reveals a preference for the Zoom and Google Docs combination (70\% of respondents) to be included in the online teacher-student interaction, in comparison with other tools they had experience with, such as Google Meet, Skype, and Discord. The most commonly cited reasons for Zoom are ease of use, high reliability and multiple means of communication (video, chat, emoticons, breakout rooms, screen sharing), whereas Google Docs is valued as a complementary tool that enables (a)synchronous whole-class collaboration. Students also positively view the feature Reactions that enable interaction in Zoom ('raise hand', various emoticons) and generally consider the possibility of direct interaction with the instructor as indispensable for learning (a faster way to receive answers, more informative, oral instructions clearer than written, easier to learn). For a significant number of respondents, breakout rooms in Zoom motivated them to focus more on the assignment (78\% with answers on the Likert scale 3, 4 and 5), collaborate with peers to reach a more complete understanding of translation issues (90\%), build confidence in one's ability to translate (69\%), share responsibility for the assignment (84\%), reduce stress (68\%) and develop negotiation and argumentation skills in anxiety-free environment (82\%). Only $20 \%$ of respondents state that this was an opportunity to "rest" from the direct lecture. A significant side-effect of using break- 
out rooms for $52 \%$ of respondents was that this was also an opportunity to "meet" other students at the time of lockdown. Such responses are indicative of various dimensions of engagement: behavioral, cognitive and emotional (cf. Fredericks et al., 2004: 61).

Preferences for Moodle and Google Classroom as learning management systems seem to be almost equally divided, although the positive features mentioned for both are similar. Moodle and Google Classroom are valued as repositories of course materials. Some respondents find Google Classroom to be a more intuitive tool. On the other hand, students dislike when a wide variety of platforms are used by different instructors at the same institution and when the tools are mostly used for frontal instruction, without much interaction. This is particularly problematic on days when students have several classes one after another with no breaks in-between. This issue has also been discussed in recent literature on remote teaching. While it has been ascertained that teachers normally combine a variety of tools, depending on their function, simultaneous use of multiple channels of communication in synchronous lessons has been found to cause stress and fatigue because it increases cognitive load and reduces comprehension, recall and retention (Ahrens et al., 2021: 263). It has also been argued that the so-called 'Zoom fatigue' results from expressive amount of close-up gaze, cognitive load, increased self-evaluation from staring at video of oneself and constraints on physical mobility (Bailensen 2021; also Ahrens et al., 2021:264). To alleviate such effects, Nordmann et al. (2020) argue that when traditional face-to-face instruction is translated into remote teaching, the instruction should be adjusted so that there is a combination of synchronous interaction and asynchronous individual and or small- group assignments and reading materials, organized in smaller distinct packages to which learners can return in their own time.

Few students reported technical difficulties in using the tools ( 3 of 75 ), but some importantly stress that living circumstances (no separate room, noise in the apartment), sometimes prevented them from using and participating in video-conferencing. This was also noticeable when students wrote their names in Google Docs at the beginning of the lesson, where they noted that they were following the assignments through Moodle and Google Docs, excluding Zoom.

Quantitative analysis. The data in Table 2 reveal that students differed in the overall level of Engagement $\left(F=5.205, p=.025, \eta_{p}^{2}=.067\right)$, with a higher mean discovered among students who participated only in online classes (G2).

Effect size, reported above as partial eta squared, is considered medium (Cohen, 1988). At this point, this result reveals that both groups were highly engaged in online courses (3.52 and 3.95 out of 5), and that G1 was less engaged than G2. Further analyses are necessary to reveal the structure of their engagement.

On the basis of responses to the question of whether they found blended or distance learning to be easier (Table 3), it can be seen that students who found online classes to be easier overall had higher levels of engagement than the students who rated online learning as more difficult. Even though the students who found online classes to be more difficult in general had lower levels of engagement, their mean scores were not lower than 3.71, which indicates that their attitude toward online learning is on the whole positive. There is no statistically sig-

Table 2: Between-groups ANOVA for differences between G1 and G2

\begin{tabular}{cccccccc}
\hline variable & student experience & $\mathrm{N}$ & Mean & SD & $F$ & $p$ & $\eta_{p}{ }^{2}$ \\
\hline Engagement & G1 Blended/Online & 28 & 3.52 & .93 & 5.205 & .025 & .067 \\
& G2 Online & 47 & 3.95 & .68 & & & \\
\hline
\end{tabular}


Table 3: Between-groups ANOVA for perceptions of the difficulty of online learning

\begin{tabular}{cccccccc}
\hline variable & & $\mathrm{N}$ & Mean & $\mathrm{SD}$ & $F$ & $p$ & $\eta_{p}^{2}$ \\
\hline Engagement & Easier & 17 & 4.04 & .77 & 2.205 & .142 & .030 \\
& More difficult & 57 & 3.71 & .82 & & & \\
\hline
\end{tabular}

nificant difference in the level of engagement between the students who found online learning easier and those who found it more difficult than blended learning. Similarly to the previous result, this result also only indicates that both groups manage to commit to the tasks and school work. It is through further analysis that the factors influencing their engagement will be revealed.

In order to determine what is the relative contribution of the type of interaction present in the students' online learning environment and its explanatory power in the students' level of (dis)engagement, a series of stepwise regressions were conducted, with the results presented in Tables 4-7.

The first two regression models investigated the predictor variables necessary for explaining the level of student (dis)engagement among the participants who were split between the students in G1 and those in G2.

Table 4: Regression coefficients of (dis)engagement for G1

\begin{tabular}{|c|c|c|c|c|}
\hline \multicolumn{2}{|r|}{ Model } & \multirow{2}{*}{$\frac{b}{1.618}$} & \multirow{2}{*}{$\begin{array}{c}S E b \\
.501\end{array}$} & \multirow[t]{2}{*}{$\mathrm{B}$} \\
\hline & (Constant) & & & \\
\hline 1 & Zoom Rooms & .570 & .144 & $.614^{* * *}$ \\
\hline & (Constant) & -.469 & .718 & \\
\hline \multirow[t]{3}{*}{2} & Zoom Rooms & .537 & .120 & $.579^{* * *}$ \\
\hline & Zoom & .522 & .146 & $.460^{* *}$ \\
\hline & (Constant) & -.237 & .674 & \\
\hline \multirow{3}{*}{3} & Zoom Rooms & .689 & .130 & $.743^{* * *}$ \\
\hline & Zoom & .630 & .144 & $.556^{* * *}$ \\
\hline & Google Docs & -.304 & .135 & $.333^{*}$ \\
\hline \multicolumn{5}{|c|}{$R^{2}=.66$ : for Step $1 R^{2} \Delta=.38$, for Step $2 R^{2} \Delta=.21$, for Step $3 \mathrm{R} 2 \Delta=.7 .{ }^{*} \mathrm{p}<.05,{ }^{* *} p<.01,{ }^{* * *} p<.00$} \\
\hline
\end{tabular}

The results of the conducted stepwise regression for the subsample which included the G1 students are presented in Table 4. At Step 1, the variable of Zoom Rooms entered the equation and was significantly related to Engagement $-F(1,26)=$ $15.741, p<.001$. The multiple correlation coefficient was .38, indicating 38\% of the variance of Engagement can be accounted for by the students' attitudes to small group collaboration in Zoom Rooms. At Step 2, the variable of frontal teacher instruction via Zoom entered the equation $(F(1,25)=12.706, p$ $<.001$ ), further explaining additional $21 \%$ of variance the level of Engagement established among the G1 students. At Step 3, the variable of whole class collaboration via Google Docs entered the equation and was statistically significant $(F(1,24)=5.090, p$ $<.05$ ), accounting for additional $7 \%$ of variation in G1 students' engagement. The final predictive model for this subsample is: Engagement $=-.237+(.689)$

* Zoom Rooms + (.630) * Zoom - (.304)* Google Docs. These students formed their engagement on 
the basis of both collaborative, more autonomous interaction in Zoom Rooms, but also on the basis of a direct guidance by the teacher in Zoom. As it will be shown, this is different from what can be seen in G2. Since the transfer to the purely online mode in translation courses was done by the same teacher who had previously, in a blended learning environment, used Moodle and Google Docs for similar purposes as in the purely online mode, the respondents in G1 were already accustomed to these tools and the instructional routines of the teacher. The only new tool was Zoom (for video-conferencing and small group collaboration), and though direct instruction was shorter and the assignments were less complex than in previous blended learning, their purpose and main characteristics were unchanged. The students' engagement with Zoom and Zoom Rooms could therefore be explained with their awareness of the purpose of each instructional routine and a conscious decision to follow them. Such a conclusion is also supported by some answers to open questions where students comment on the reasons for participating in sessions on Zoom. Other studies also confirm that previous experience with online classes means less difficulty in the transfer to purely online instruction in higher education institutions (Neure \& De Miguel, 2020, cited in Jelińska \& Paradowski, 2021:305).

Table 5: Regression coefficients of (dis)engagement for G2

\begin{tabular}{ccccc}
\hline & Model & $b$ & SE $b$ & $B$ \\
\hline 1 & (Constant) & 1.768 & .337 & \\
& Zoom Rooms & .588 & .088 & $.704^{* * *}$ \\
\hline \multicolumn{4}{c}{$R^{2}=.49 .^{* * *} p<.001$} \\
\end{tabular}

In investigating the contribution of predictor variables of Engagement among students from G2, at Step 1 of the analysis the variable of Zoom Rooms entered into the regression equation and was significantly related to Engagement $-F(1,45)=44.138, p$ $<.001$ (Table 5). The multiple correlation coefficient was .49 , indicating approximately $49 \%$ of the variance of Engagement for G2 could be accounted for by their attitudes towards Zoom Rooms. The variables that did not enter into the equation were the teacher's frontal instruction via Zoom at Step 2 ( $t$ $=-.333, p>.05)$ and whole class collaboration in Google Docs at Step $3(t=1.413, p>.05)$. Therefore, the regression equation for predicting Engagement can be represented as: Engagement $=1.768+$ (.588) * Zoom Rooms. Positive attitudes towards Zoom Rooms have the highest power in explaining the type of students' engagement. A positive attitude towards Zoom Rooms in $49 \%$ of cases predicts how engaged the students will be in class, whereas their attitudes towards Zoom and Google Docs do not seem to contribute significantly to their level of engagement. Zoom Rooms offer opportunities for working on a task in a collaborative setting, without direct involvement of the teacher. In smaller groups the students are publicly evaluated by a significantly lower number of other students and, importantly, they are not evaluated by the teacher. At the same time, the smaller team size means that they have to be more actively involved in work and cannot count on others stepping in, as they normally would in large groups. In other words, G2 students who participated in small group discussions in Zoom Rooms were accustomed to forming their level of engagement without direct guidance, supervision and involvement of the teacher. This could be explained by their unfamiliarity with the teacher (no previous experience with the blended learning scenario and the relevance of introductory sessions) and their preference to learn about all relevant information from the peers. Various investigators of remote teaching and learning stress that virtual communities built specifically for a university-level course can facilitate learning in online environments (Ahrens et al., 2021:273; Herman \& Gomez, 2009:67; Wang \& Wang, 2021). Valentine and Wong (2021:243) also found that collaborative peer work can help students expand their individual knowledge as well as assuage feelings of isolation in virtual environment. 
Table 6: Regression coefficients of (dis)engagement for "Online learning is easier"

\begin{tabular}{ccccc}
\hline & Model & $b$ & SE $b$ & $B$ \\
\hline \multirow{2}{*}{1} & (Constant) & 1.148 & .516 \\
& Zoom Rooms & .729 & .128 & $.802^{* * *}$ \\
\hline \multicolumn{5}{c}{$R^{2}=.28 .{ }^{* * *} p<.001$} \\
\hline
\end{tabular}

The second two regression models investigated the predictor variables necessary for explaining the level of student (dis)engagement among the participants who were again split into two subsamples. The first subsample (Table 6) included the students who reported they found online learning environment easier than the blended learning environment. At Step 1 of the analysis, the variable of Zoom Rooms entered into the regression equation and was significantly related to Engagement $-F(1,18)=$ $32.345, p<.001$. The multiple correlation coefficient was .28 , indicating approximately $28 \%$ of the variance of Engagement among students who perceived online learning to be easier than their previous computer aided face-to-face learning could be accounted for by their attitudes towards Zoom Rooms. The variable that did not enter into the equation was frontal teacher's instruction via Zoom at Step $2(t=$ $1.323, p>.05)$ and whole class collaboration in Google Docs at Step $3(t=-.423, p>.05)$. Therefore, the regression equation for predicting Engagement can be represented as: Engagement $=1.148+(.729)$ * Zoom Rooms. The students who are comfortable in an online learning setting form their engagement on the basis of positive attitudes and experiences with Zoom Rooms, although, with a $28 \%$ of variation explained, further research is needed to uncover additional factors that influence the students' level of engagement.
Table 7: Regression coefficients of (dis)engagement for "Online learning is more difficult"

\begin{tabular}{|c|c|c|c|c|}
\hline & Model & $\mathrm{b}$ & SE b & B \\
\hline \multirow{2}{*}{1} & (Constant) & 1.831 & .325 & \\
\hline & Zoom Rooms & .547 & .093 & $.615^{* * *}$ \\
\hline \multirow{3}{*}{2} & (Constant) & 1.019 & .436 & \\
\hline & Zoom Rooms & .494 & .091 & $.556^{* * *}$ \\
\hline & Zoom & .263 & .100 & $.269^{* * * x}$ \\
\hline & $=.44:$ for Step & $\begin{array}{l}\Delta=.37 \\
p<.0\end{array}$ & tep 2 & $=.7 .^{* * *}$ \\
\hline
\end{tabular}

The second subsample (Table 7 ) included the students who reported they found online learning environment more difficult to participate in than in the blended learning environment. At Step 1, the variable of Zoom Rooms entered the equation and was significantly related to Engagement - $F(1,57)$ $=34.689, p<.001$. The multiple correlation coefficient was .44, indicating $44 \%$ of the variance of Engagement can be accounted for by the students' attitudes towards Zoom Rooms. At Step 2, the variable of Zoom entered the equation $(F(1,56)=22.643$, $p$ $<.001$ ), further explaining additional $7 \%$ of variance the level of Engagement established among the students who found the online learning environment to be more difficult. The variable that did not enter the equation was Google Docs $(t=1.323, p>.05)$, which means that the regression equation for predicting Engagement for students who believe online learning is more difficult than blended learning is: Engagement $=1.019+(.494) *$ Zoom Rooms $+(.263) *$ Zoom. Students who are less comfortable in an online setting, structure their level of engagement on the basis of the combination of Zoom Rooms and Zoom. They do participate in collaborative work, however, they also show a need for clear guidance. 


\section{Conclusions}

The purpose of the current study was to investigate the level of students' (dis)engagement during synchronous online classes in relation to a) whether they had previous experience with blended learning or not, b) their overall attitudes towards online classes and c) the type of interaction in the online learning environment. The qualitative analysis of the data has confirmed our theoretical understanding of the complexity of the concept of engagement (cf. Fredericks et al., 2004: 61), as the results reveal that students formed their engagement on the combination of behavioural, cognitive and emotional dimensions. The results show that both the students who had been exposed to blended learning environment in previous translation courses (G1) and the students had not (G2) reported medium-tohigh levels of online engagement. However, the influences at the core of the engagement for the two groups differed significantly. The students who had previous experience with blended learning formed their engagement on the basis of both collaborative peer interaction in Zoom Rooms and a direct guidance by the teacher. The students with no such experience formed their engagement solely on the basis of positive attitudes towards online peer interaction (in Zoom Rooms), whereas their attitudes towards Zoom and Google Docs did not contribute to their level of engagement. From this, it is possible to infer that the respondents who were more familiar with the tools, the teacher and her most common instructional routines as they had already complet- ed a blended learning course prior to the lockdown, were often engaged in more segments of the online course than those who were not.

Regarding the type of interaction in online learning environment, it is possible to conclude that student engagement was most fostered by the activities and tools that focused on small group (in Zoom Rooms) and whole class collaboration (Google Docs). Google Docs was particularly helpful in allowing all participants in the class to keep track of what the whole class was doing, enabling communication between groups with minimal interference from the teacher. By colour-coded highlighting the best solutions in peer translations, students were able to express positive feedback to other members in the class. For the teacher, highlighting was an effective means of nudging students to reconsider and discuss problematic issues in order to come to the solution relying on peer collaboration rather than on the teacher's direct instruction.

The most important practical implication stemming from the results echoes other recent studies on online learning (Ahrens et al., 2021:259; Nordmann et al., 2021) and stresses the need for explanations and instructions to be more explicit and repeated more often. These include not only specific directions about the end date by which students should have viewed a lecture, completed a reading, done assignments and similar, which, according to Nordmann (2021), provide students with a structure and help them build a routine when other cues are missing, but also the logic of the course, learning goals and the purpose of the activities.

\section{References}

- Ahrens, B., Beaton-Thome, M. and Rütten, A. (2021). The pivot to remote online teaching on the MA in Conference Interpreting in Cologne: Lessons learned from and unexpected experience. The Journal of Specialised Translation, 36, 251-284.

- Aubrey, S., King, J. \& Almukhaild, H. (2020). Language learner engagement during speaking tasks: A longitudinal study. RELC Journal, 51 (1), 1-15. DOI: 10.1177/0033688220945418

- Bailensen, J. N. (2021). Nonverbal overload: A theoretical argument for the causes of Zoom fatigue. Technology, Mind, and Behavior, 2 (1). DOI: 10.1037/tmb0000030 
- Boelens, R., Voet, M. \& De Wever, B. (2018). The design of blended learning in response to student diversity in higher education: Instructors' views and use of differentiated instruction in blended learning. Computers \& Education, 120, 197-212. DOI: 10.1016/j.compedu.2018.02.009

- Carless, D. (2015). Exploring learning-oriented assessment processes. Higher Education, 69 (6), 963-976. DOI: 10.1007/s10734-014-9816-Z

- Christenson, S. L., Reschly, A. L. \& Wylie, C. (Eds.). (2012). Handbook of research on student engagement. New York: Springer.

- Dörnyei, Z. (2019). Towards a better understanding of the L2 Learning Experience, the Cinderella of the L2 Motivational Self System. Studies in Second Language Learning and Teaching, 9 (1), 19-30.

- Eraković, B. \& Lazović, V. (2017). Prednosti i nedostaci sistema za podršku učenju u konstruktivističkom pristupu nastavi prevođenja iz perspektive studenata: Mudl i Edmodo. Nastava i vaspitanje, 66 (2), 259-272. DOI:10.5937/nasvas1702259E

- Eraković, B. (2017). To what extent do student expectations influence the application of a collaborative learning model? In: Hagemann, S., Neu, J. \& Walter, S. (Eds). Translationslehre und Bologna-Prozess: Unterwegs zwischen Einheit und Vielfalt / Translation/Interpreting Teaching and the Bologna Process: Pathways between Unity and Diversity (283-307). TransÜD 87. Berlin: Frank \& Timme.

- Finn, J. \& Zimmer, K. (2012). Student engagement: What is it? Why does it matter? In: Christenson, S., Reschly, A. \& Wylie, C. (Eds.). Handbook of Research on Student Engagement (97-132). New York: Springer.

- Fredricks, J. A., Blumenfeld, P. C. \& Paris, A. H. (2004). School engagement: Potential of the concept, state of the evidence. Review of Educational Research, 74 (1), 59-109.

- Herman, P. \& Gomez, L. M. (2009). Taking guided learning theory to school. Reconciling the cognitive, motivational and social contexts of instruction. In: Tobias, S. \& Duffy, T. M. (Eds.). Constructivist instruction: success or failure? (62-81). New York: Routledge.

- Jelińska, M. \& Paradowski, M. B. (2021). Teachers' engagement in and coping with emergency remote instruction during COVID-19-induced school closures: A multinational contextual perspective. Online Learning Journal, 25 (1), 303-328. DOI: 10.24059/olj.v25i1.2492

- Johnson, A. (2020). Online teaching with Zoom. A guide for teaching and learning with videoconference platforms. Retrieved March 19, 2021 from www: https://excellentonlineteaching.com

- Kahu, E. R. (2013). Framing student engagement in higher education. Studies in Higher Education, 38 (5), 758-773. DOI: 10.1080/03075079.2011.598505

- Kim, M. K., Kimb, S. M., Khera, O. \& Getman, J. (2014). The experience of three flipped classrooms in an urban university: an exploration of design principles. Internet and Higher Education, 22, 37-50. DOI: 10.1016/j. iheduc.2014.04.003

- Kiraly, D. (2000). A social-constructivist approach to translator education: Empowerment from theory to practice. Manchester: St. Jerome Publishing.

- Kiraly, D. (2006). Beyond social constructivism. Complexity theory and translator education. Translation and interpreting studies, 1 (1), 68-86.

- Kiraly, D. (2015). Occasioning translator competence. Moving beyond social constructivism toward a postmodern alternative to instructionism. Translation and Interpreting Studies, 10 (1), 8-32. 
- Kiraly, D., Rüth, L., Signer, S., Stederoth, K. \& Wiedmann, M. (2019). Enhancing translation course design and didactic interventions with e-learning: Moodle and Beyond. In: Kiraly, D. \& Massey, G. (Eds.). Towards Authentic Experiential Learning in Translator Education (2nd Edition) (103-130). Newcastle: Cambridge Scholars Publishing.

- Kirschner, P. A., Sweller, J., Kirschner, F. \& Zambrano, R. J. (2018). From cognitive load theory to collaborative cognitive load theory. International Journal of Computer-Supported Collaborative Learning, 13 (2), 213233. DOI: 10.1007/s11412-018-9277-y

- Lopez, S. J. (2011). Strengths-based education and student engagement. Washington, DC: Gallup Inc.

- Newmann, F., Wehlage, G. G. \& Lamborn, S. D. (1992). The significance and sources of student engagement. In: Newmann, F. (Ed.). Student engagement and achievement in American secondary schools (11-39). New York: Teachers College.

- Nordmann, E., Horlin, C., Hutchison, J., Murray, J. A., Robson, L., Seery, M. K. et al. (2020). Ten simple rules for supporting a temporary online pivot in higher education. PLoS Comput Biol, 16 (10): e1008242. DOI: 10.1371/journal.pcbi.1008242.

- Nuere, S. \& De Miguel, L. (2020). The digital/technological connection with COVID-19: An unprecedented challenge in university teaching. Technology, Knowledge and Learning. DOI: 10.1007/s10758-020-09454-6

- Pešikan, A. (2010). Savremeni pogled na prirodu školskog učenja i nastave - socio-konstruktivističko gledište i njegove praktične implikacije. Psihološka istraživanja, 13 (2), 157-184.

- Reschly, A. \& Christenson, S. L. (2006a). Prediction of dropout among students with mild disabilities: A case for the inclusion of student engagement variables. Remedial and Special Education, 27, 276-292.

- Reschly, A. \& Christenson, S. L. (2006b). School completion. In: Bear, G. \& Minke, K. (Eds.). Children's needs III: Understanding and addressing the developmental needs of children (103-113). Bethesda, MD: National Association of School Psychologists.

- Valentine, E. \& Wong, J. (2021). Pathway into translation online teaching and learning: three case-studies. The Journal of Specialised Translation, 36, 220-250.

- Vygotsky, L. (1978). Mind in society: The development of higher psychological processes. Cambridge, MA: Harvard University Press.

- Wanner, T. \& Palmer, E. (2015). Personalising learning: Exploring student and teacher perceptions about flexible learning and assessment in a flipped university course. Computers \& Education, 88, 354-369. DOI: 10.1016/j.compedu.2015.07.008

- Wu, D. \& Wei, L. (2021). Online teaching as the new normal: Understanding translator trainers' self-efficacy beliefs. The Journal of Specialised Translation, 36, 301-326. 


\section{Борислава Р. Ераковић \\ Јагода П. Топалов \\ Универзитет у Новом Саду, Филозофски факултет, Нови Сад, Србија}

\section{НАСТАВА И УЧЕњЕ ПУТЕМ МУДЛА, ГУГЛОВИХ ДОКУМЕНАТА И ЗУМА: АНГАЖОВАЮЕ СТУДЕНАТА У (А)СИНХРОНОМ НАСТАВНОМ ОКРУЖЕЊУ}

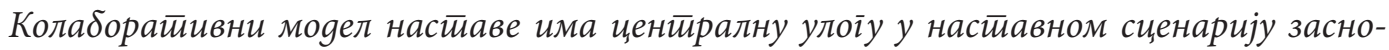
ваном на социоконстирукииивисиичкој еиистемолоїији (Vigotski, 1978). Улоїа настивника

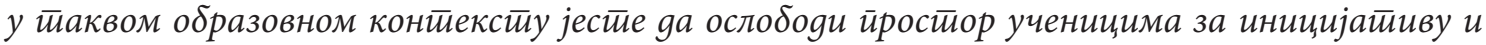
ауйономно овлаgаваюе знаюем, избеіава фронииалну настиву и да усмерава, иоомаже и воgи онgа каgа се йокаже gа је тио ученицима йойребно. Уусловима онлајн-насииаве, која се реализује йуиеме јеgноі канала комуникације, настивник иеже исиуғава тио очекиваюе, у највећој

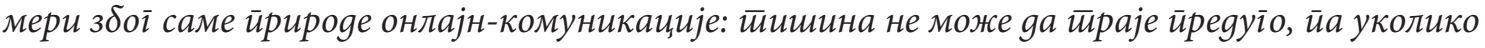

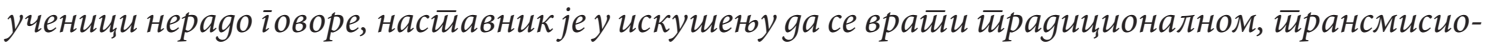
нисиичком моделу настиаве. Комбинована, йонекаg истиовремена уйойреба неколико начина комуникаиије иууием интиернетиа може сииворииии окружеюе у којем се ученицима омоіу ћава колаборација у малим іруйама, а насииавнику gа иниеервенише само каgа је йо йойребно.

У раяу се исиитиује ниво анїажованостии ученика у јеgном ииаквом сценарију реализованом йомоћу Mygла (Moоdle), Гуіллових gокуменайа (Google Docs) и соба на йлайборми зум (Zоom Rooms) за асинхрону и синхрону насииаву. Анїажоване gебинишемо као учешће ученика у актииностиима и заяацима, као и њихову бихевиоралну, коіннитивну и афектиивну укључености у настиавни йроцес (Kahu, 2013, Newmann et al., 1992, Fredricks et al., 2004). Исйраживаюе у овом раяу је усмерено ка исиитииваюу (не)аніажованостии ученика у односу на

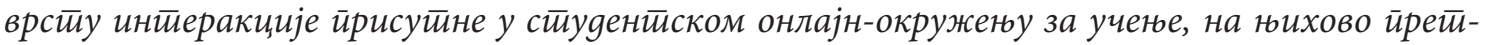
ходно искустиво у хибрияној насйави и на юихов оитиии стиав иррема онлајн-часовима.

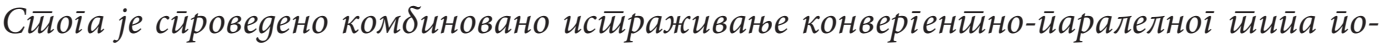

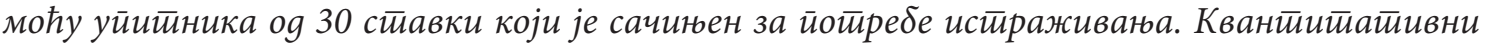
йоgаии су йрикуйљени йомоћу стиавки које су исииитаници оценивали на иеетестиеиееној Ли-

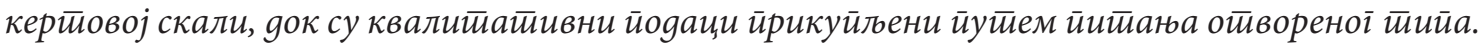
Уӣитиником су исиитианици йозвани gа изразе своје сииавове ирема алаииима који се корисиие за колабораииивне заяатике, иррезенииаиију материјала за учење и издаваюе настиавни-

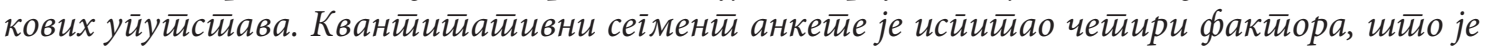

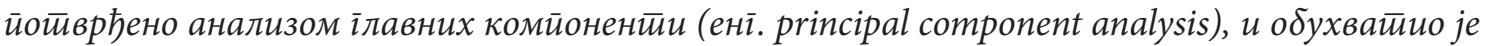
зависну варијаблу аніажоваюа и независне варијабле сииавова иррема фрониталној насииави иуиеем йлайоформе Зум, иррема сараяничком раяу у малим іруйама у „собама“ у зуму, и йрема сараяничком раяу иеле ірруие у Гуілловим докуменииима. Исиичйани узорак се састиојао оg

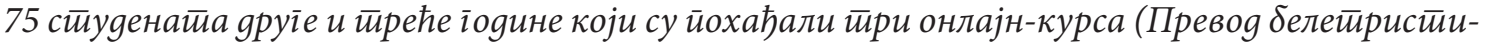

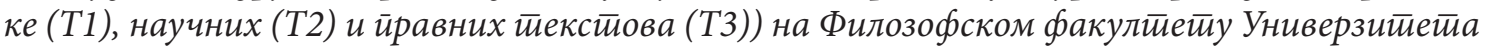

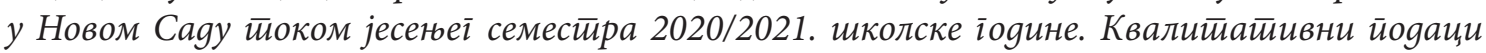




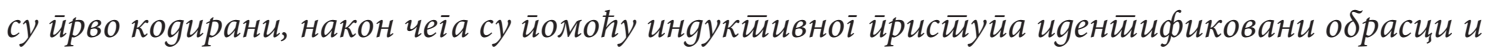

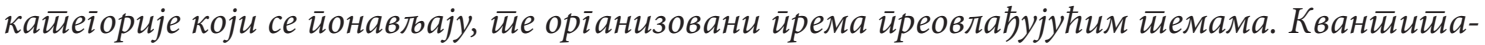

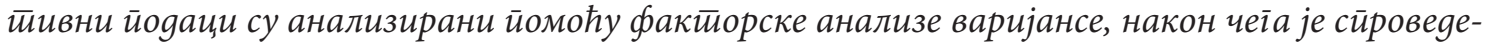

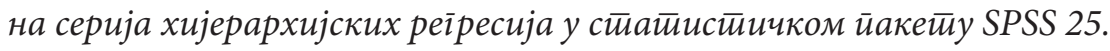

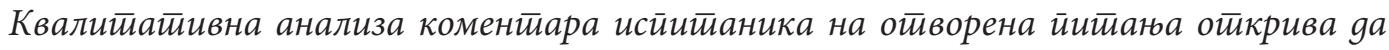

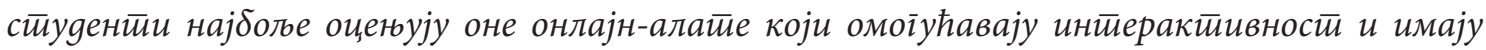

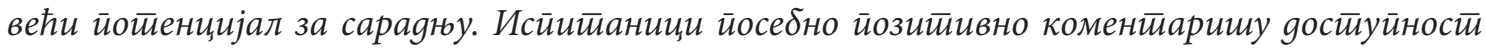

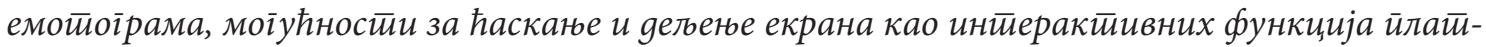
борме Зум, зайим моіу ћности за сараgюу у малим іруйама у собама на Зуму, као и за сараgюу иеле іруйе у окружеюу Гуілтових докуменайа.

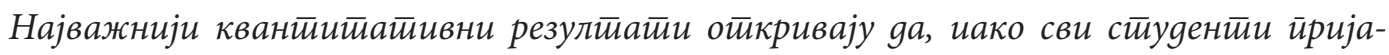

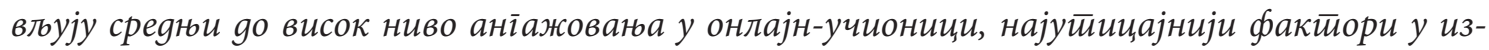

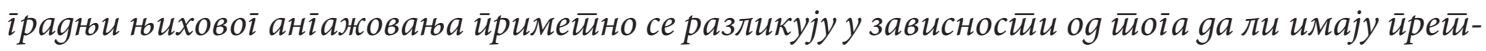

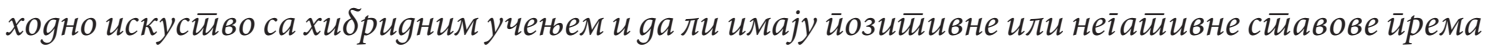

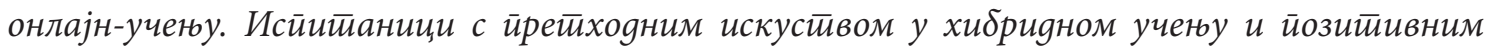
стиавом иррема онлајн-учеюу своје аніпжоваюе заснивају и на вриюачкој интиеракиији у со-

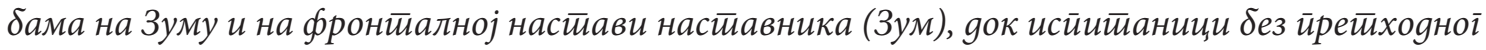

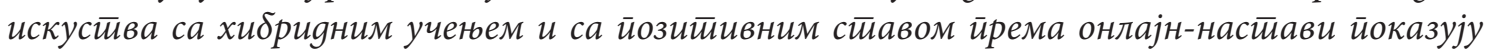
аніажованости само у раяу у малим іруйама у собама на Зуму. Друіим речима, уйознайосии

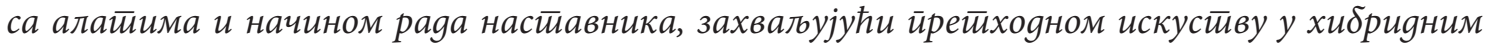
облиицма настиаве, уйиче на аніажованости ученика у већем броју сеіменайа онлајн-настиавe.

Pag нуgи широко йрименљиве сиенарије за онлајн-насйаву и увия у рефлексије ученика

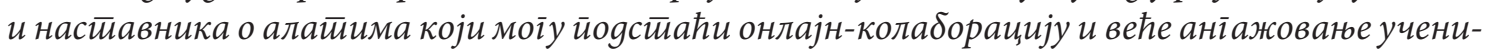
ка у настиави и учену на даљину, у хибрияном или ученуу иомоћу рачунара.

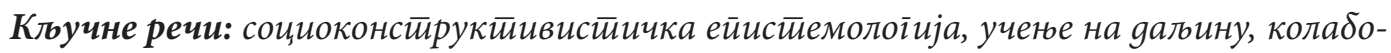

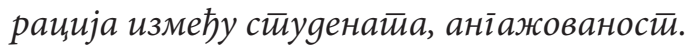

